\title{
INVESTIGATION OF MENTAL HEALTH OF AMATEUR AND PROFESSIONAL FOOTBALL PLAYERS IN THE COVID-19 PANDEMIC PERIOD
}

\author{
Hasan Akgün ${ }^{1 \mathrm{i}}$, \\ Mürsel Biçer ${ }^{2 i}$, \\ Mehmet Vural ${ }^{3}$ \\ ${ }^{1}$ Gaziantep University, \\ Health Sciences Institute, \\ Turkey \\ ${ }^{2}$ Prof. Dr., \\ Gaziantep University, \\ Health Sciences Institute, \\ Turkey \\ ${ }^{3}$ Gaziantep University, \\ Faculty of Sport Sciences, \\ Turkey
} Abstract:
The aim of this study is to investigate the mental health of amateur and professional
football players during the Covid-19 pandemic period. For this purpose, 49 amateur
female, 68 amateur male and 34 professional male football players participated in the
study. The Pittsburgh Sleep Quality Index consisting of 24 questions and the Beck
Depression Scale consisting of 21 questions were applied to measure the sleep quality
and depression symptoms of the participants. The obtained data were analyzed with the
SPSS 22.0 program. Values were presented as minimum, maximum, mean, standard
deviation, and standard error. Significance level was accepted as p<0.05. The
Kolmogorov-Smirnov test was used to test for normality. One Way Anova and LSD tests
were performed to analyze the differences between groups. There were significant
differences in BDI total score, subjective sleep quality and sleep disorder parameters
when grouped by age. (p<0.05) Significant differences were found in BDI total score,
subjective sleep quality, sleep latency, sleep disturbance, and total PUKI score parameters
when grouped by sport categories. (p<0.05) No significant difference was found in any
parameter in grouping the participants according to sports age. (p $>0.05$ ) As a result, it
can be said that the sleep quality of amateur women and amateur men is bad, and the
sleep quality of professional men is good during the Covid-19 pandemic period. It can be

${ }^{i}$ Correspondence: email hasanakguntr96@gmail.com 
said that the depression symptoms of amateur women are bad, the amateur men's group is moderate, and the depression symptoms of professional men are good.

Keywords: Covid-19, depression, mental health, sleep quality, soccer

\section{Introduction}

Looking from the past to the present, global diseases have created great negative effects on people's lifestyles and have caused bad changes in people's lives, even for a certain period. Epidemics that occurred in the past centuries have the same characteristics as today's epidemics. In addition to its negative social, economic and cultural effects, it has made it necessary to limit the vital activities of individuals. When the Severe Acute Respiratory Syndrome Coronavirus-2 (SARS-CoV-2) is examined, it is seen that this new type of coronavirus occurred in Wuhan, China. The Covid-19 disease, in which this situation occurred, spread rapidly all over the world, especially in Asia and Europe. When the Covid-19 virus is examined in the laboratory environment, it has been observed that after entering the human body, it has great negative effects on the respiratory system, especially the cardiovascular system, blood cells, and musculoskeletal systems. (1)

With the rapid spread of Covid-19 all over the world, the restrictions that occurred have started to be implemented in Turkey as well. Various obstacles have led to mental and physical disorders in individuals. Although the measures taken were made in order for people to maintain their health and life, the uncertainty of the process, inactive life, being away from social activities brought different health problems in people. Human beings need to act continuously since the day they exist. Therefore, the metabolism is in constant motion. Based on this, when the human body is inactive for a certain period of time, it loses some of its existing functions and the possibility of diseases such as musculoskeletal system disease, heart disease, overweight, diabetes, hypertension and cancer increases. (2) $t$ is seen that continuous physical activity has a great share in preventing the negative effects of epidemic diseases such as Covid-19, as well as having a significant effect on mental disorders such as coping with distress, avoiding worries, and preventing stress. Apart from its physical and mental effects, it also has a social and economic healing effect. $(3,4)$

When sports are examined from the past to the present, it is known that it has a positive effect on the physical and spiritual development of people. In order for individuals to continue their daily life activities, there must be a state of complete physical and mental well-being. This is achieved through various physical activities. An individual must be physically, mentally and socially healthy in order to help his social environment. Studies showing that physical activity has great positive effects on the health of the individual are increasing day by day. It is known that sports have very important effects in the prevention and treatment of many diseases, even delaying aging. (5) 
Sports have effects such as the mental development of children, the emergence of their abilities, the development of sudden movements, the ability to think and apply quickly, and the responsibility to own the result of the decision they make. Sport is a tool for people to lead a healthy, peaceful and joyful life. Based on this, when sports and mental health issues are related; Research has shown that sports make a significant contribution to individuals' feeling vigorous, healthy, good and happy in every aspect of their lives. $(6,7)$

Scientific studies are needed to examine the mental and physical effects of the Covid-19 virus on amateur and professional football players, and to analyze the problems it causes, in order to investigate the negative effects of a sedentary, social and sporting life caused by the coronavirus as a result of the researches we have examined. In this context, the aim of our study will be to investigate the mental health of amateur and professional football players during the Covid-19 pandemic period.

\section{Method}

At our research, 151 people (102 men, 49 women) between the ages of 18-35 participated voluntarily. The subjects participating in the research consist of people who actively continue their football life. The Pittsbugh Sleep Quality Index (PSQI) consisting of 19 questions and the Beck Depression Scale (BDI) consisting of 21 questions were applied to the participants in the study.

The research population consists of male and female athletes who play football actively. The research sample consists of 151 active football players between the ages of 18-35 who participated in the research from different areas of Turkey. 49 of the athletes participating in the research are amateur women, 68 are amateur men and 34 are professional male athletes. The average age range of the athletes participating in the research is 21.68 .

SPSS 22.0 (SPSS Inc., Chicago, Illinois, USA) program was used for statistical processing of the data. Values were presented as minimum, maximum, mean, standard deviation, and standard error. Significance level was accepted as $p<0.05$. KolmogorovSmirnov test was used for normality test. One Way Anova and LSD tests were performed to analyze the differences between groups.

\section{Findings}

According to Table 3.1, the grouping of the participants according to the sports categories was examined. As a result of the analysis, no significant difference was found in the parameters of sleep duration, habitual sleep efficiency and sleep medication use ( $p>$ $0.05)$. 
Table 3.1: Analysis of the participants' BDI total score,

PUKI total score and PUKI sub-components by sport categories

\begin{tabular}{|c|c|c|c|c|c|c|c|}
\hline & & Mean & Std. D. & Std. E. & $\mathbf{F}$ & $\mathbf{P}$ & difference \\
\hline \multirow{3}{*}{ BDI Total Score } & Amateur Woman a & 17,4898 & 10,42657 & 1,48951 & \multirow{3}{*}{11,965} & \multirow{3}{*}{, 000} & \multirow{3}{*}{$\begin{array}{c}a-b-c \\
c-b\end{array}$} \\
\hline & Amateur Male b & 11,1176 & 9,69464 & 1,17565 & & & \\
\hline & Professional Male c & 7,8235 & 6,58037 & 1,12852 & & & \\
\hline \multirow{3}{*}{ Subjective Sleep quality } & Amateur Woman & 1,2041 & 1,06026 & 15147 & \multirow{3}{*}{8,059} & \multirow{3}{*}{, 000} & \multirow{3}{*}{$\begin{array}{c}a-b-c \\
b-c\end{array}$} \\
\hline & Amateur Male & ,8529 & 88545 & , 10738 & & & \\
\hline & Professional Male & ,3824 & ,73915 & ,12676 & & & \\
\hline \multirow{3}{*}{ Sleep Latency } & Amateur Woman & 1,4898 & 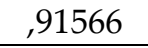 & 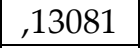 & \multirow{3}{*}{7,305} & \multirow{3}{*}{,001 } & \multirow{3}{*}{$\begin{array}{c}a-b-c \\
b-c\end{array}$} \\
\hline & Amateur Male & 1,2647 & 1,04550 & , 12679 & & & \\
\hline & Professional Male & 6765 & 87803 & ,15058 & & & \\
\hline \multirow{3}{*}{ Sleep Time } & Amateur Woman &, 5510 & ,84314 & 12045 & \multirow{3}{*}{1,852} & \multirow{3}{*}{, 161} & \\
\hline & Amateur Male & ,3235 & ,55828 & ,06770 & & & \\
\hline & Professional Male & ,3235 & ,63821 & , 10945 & & & \\
\hline \multirow{3}{*}{ Habitual Sleep Activity } & Amateur Woman & 4898 & ,71071 & , 10153 & \multirow{3}{*}{,713 } & \multirow{3}{*}{, 492 } & \\
\hline & Amateur Male & ,5294 & ,96924 & ,11754 & & & \\
\hline & Professional Male & ,3235 & ,68404 & ,11731 & & & \\
\hline \multirow{3}{*}{ Sleeping disorder } & Amateur Woman & 1,6531 & ,69375 & ,09911 & \multirow{3}{*}{13,345} & \multirow{3}{*}{, 000} & \multirow{3}{*}{$\begin{array}{c}a-b-c \\
b-c\end{array}$} \\
\hline & Amateur Male & 1,1912 & ,65237 & , 07911 & & & \\
\hline & Professional Male & ,9118 & ,66822 & ,11460 & & & \\
\hline \multirow{3}{*}{ Sleeping Pill Use } & Amateur Woman & ,0204 & ,14286 & ,02041 & \multirow{3}{*}{,448 } & \multirow{3}{*}{,640 } & \\
\hline & Amateur Male & , 0588 & ,29333 & ,03557 & & & \\
\hline & Professional Male & ,0294 & , 17150 & ,02941 & & & \\
\hline \multirow{3}{*}{ Total PUKI Score } & Amateur Woman & 6,7143 & 3,26599 & ,46657 & \multirow{3}{*}{12,267} & \multirow{3}{*}{, 000} & \multirow{3}{*}{$\begin{array}{c}a-b-c \\
b-c\end{array}$} \\
\hline & Amateur Male & 5,1618 & 2,54283 & ,30836 & & & \\
\hline & Professional Male & 3,6176 & 2,66304 & 45671 & & & \\
\hline
\end{tabular}

However, when the BDI total score parameter was analyzed, it was found that there was a significant difference in favor of the amateur female group as a result of comparing the amateur women, amateur men and professional men groups $(\mathrm{p}<0.05)$. When the BDI total score parameter was analyzed, it was found that there was a significant difference in favor of the professional male group as a result of the comparison between the amateur male group and the professional male group $(p<0.05)$. When the subjective sleep quality, sleep latency, sleep disturbance and total PUKI score parameters were examined, a significant difference was found in favor of amateur women as a result of comparing the groups of amateur women, amateur men and professional men $(p<0.05)$. As a result of the examination made in these parameters, a significant difference was found in favor of the amateur male group as a result of comparing the amateur male and professional male groups $(\mathrm{p}<0.05)$. 
Table 3.2 Analysis of BDI total score, PUKI total score and PUKI

subcomponents according to the sports age of the participants

\begin{tabular}{|c|c|c|c|c|c|c|c|}
\hline & & $\mathbf{N}$ & Mean & Std. D. & Std. E & $\mathbf{F}$ & $\mathbf{p}$ \\
\hline \multirow{3}{*}{ BDI Total Score } & $1-5$ years & 36 & 13,56 & 9,32108 & 1,55351 & \multirow{3}{*}{,405 } & \multirow{3}{*}{668} \\
\hline & 5-9 years & 42 & 12,69 & 9,84140 & 1,51856 & & \\
\hline & 9 and above & 73 & 11,75 & 10,50368 & 1,22936 & & \\
\hline \multirow{3}{*}{ Subjective Sleep Quality } & $1-5$ years & 36 & ,8611 & 1,01848 & , 16975 & \multirow{3}{*}{475} & \multirow{3}{*}{623} \\
\hline & 5-9 years & 42 & ,9762 & 99971 & ,15426 & & \\
\hline & 9 and above & 73 & 7945 & ,91225 & 10677 & & \\
\hline \multirow{3}{*}{ Sleep Latency } & $1-5$ years & 36 & 1,0833 & 1,07902 & ,17984 & \multirow{3}{*}{1,938} & \multirow{3}{*}{148} \\
\hline & $5-9$ years & 42 & 1,0238 & ,86920 & ,13412 & & \\
\hline & 9 and above & 73 & 1,3699 & 1,03423 & 12105 & & \\
\hline \multirow{3}{*}{ Sleep Time } & $1-5$ years & 36 &, 5000 &, 77460 & ,12910 & \multirow{3}{*}{, 534} & \multirow{3}{*}{588} \\
\hline & 5-9 years & 42 & ,3571 & 65598 & ,10122 & & \\
\hline & 9 and above & 73 & 3699 & 65631 & ,07682 & & \\
\hline \multirow{3}{*}{ Habitual Sleep Activity } & $1-5$ years & 36 & ,5556 & ,99841 & , 16640 & \multirow{3}{*}{ 766 } & \multirow{3}{*}{467} \\
\hline & 5-9 years & 42 & ,5476 & ,73923 & 11407 & & \\
\hline & 9 and above & 73 & ,3836 & ,79285 & ,09280 & & \\
\hline \multirow{3}{*}{ Sleeping disorder } & $1-5$ years & 36 & 1,2222 & ,54043 & ,09007 & \multirow{3}{*}{ 152 } & \multirow{3}{*}{859} \\
\hline & 5-9 years & 42 & 1,3095 & ,74860 & 11551 & & \\
\hline & 9 and above & 73 & 1,2877 & ,79021 & ,09249 & & \\
\hline \multirow{3}{*}{ Sleeping Pill Use } & $1-5$ years & 36 & ,0556 & 33333 & ,05556 & \multirow{3}{*}{, 189 } & \multirow{3}{*}{828} \\
\hline & 5-9 years & 42 & , 0238 & , 15430 & ,02381 & & \\
\hline & 9 and above & 73 & ,0411 & 19989 & ,02339 & & \\
\hline \multirow{3}{*}{ Total PUKI Score } & $1-5$ years & 36 & 5,2500 & 3,01780 & ,50297 & \multirow{3}{*}{,013 } & \multirow{3}{*}{,987 } \\
\hline & 5-9 years & 42 & 5,3571 & 3,10642 & ,47933 & & \\
\hline & 9 and above & 73 & 5,3288 & 3,02790 & 35439 & & \\
\hline
\end{tabular}

According to Table 3.2, the grouping of the participants according to the athlete's age was examined. As a result of the analysis, no significant difference was found in any of the parameters. $(\mathrm{p}>0.05)$

Table 3.3: Analysis of the participants' BDI total score,

PUKI total score and PUKI sub-components by sport categories

\begin{tabular}{|c|c|c|c|c|c|c|c|}
\hline & & Mean & Std. D. & Std. E. & $\mathbf{F}$ & $\mathbf{P}$ & difference \\
\hline \multirow{3}{*}{ BDI Total Score } & Amateur Woman a & 17,4898 & 10,42657 & 1,48951 & \multirow{3}{*}{11,965} & \multirow{3}{*}{, 000} & \multirow{3}{*}{$\begin{array}{c}a-b-c \\
c-b\end{array}$} \\
\hline & Amateur Male b & 11,1176 & 9,69464 & 1,17565 & & & \\
\hline & Professional Male c & 7,8235 & 6,58037 & 1,12852 & & & \\
\hline \multirow{3}{*}{ Subjective Sleep Quality } & Amateur Woman & 1,2041 & 1,06026 & 15147 & \multirow{3}{*}{8,059} & \multirow{3}{*}{, 000} & \multirow{3}{*}{$\begin{array}{c}a-b-c \\
b-c\end{array}$} \\
\hline & Amateur Male & 8529 & ,88545 & ,10738 & & & \\
\hline & Professional Male & 3824 & 73915 & 12676 & & & \\
\hline \multirow{3}{*}{ Sleep Latency } & Amateur Woman & 1,4898 & ,91566 & 13081 & \multirow{3}{*}{7,305} & \multirow{3}{*}{, 001} & \multirow{3}{*}{$\begin{array}{c}a-b-c \\
b-c\end{array}$} \\
\hline & Amateur Male & 1,2647 & 1,04550 & , 12679 & & & \\
\hline & Professional Male & 6765 & 87803 & , 15058 & & & \\
\hline \multirow{3}{*}{ Sleep Time } & Amateur Woman & ,5510 & ,84314 & ,12045 & \multirow{3}{*}{1,852} & \multirow{3}{*}{, 161} & \\
\hline & Amateur Male & ,3235 & ,55828 & , 06770 & & & \\
\hline & Professional Male & ,3235 & 63821 & 10945 & & & \\
\hline Habitual Sleep Activity & Amateur Woman & 4898 & ,71071 & 10153 & 713 & ,492 & \\
\hline
\end{tabular}




\begin{tabular}{|c|c|c|c|c|c|c|c|}
\hline & Amateur Male & ,5294 & ,96924 & ,11754 & & & \\
\hline & Professional Male & ,3235 & ,68404 & ,11731 & & & \\
\hline \multirow{3}{*}{ Sleeping Disorder } & Amateur Woman & 1,6531 & ,69375 & ,09911 & \multirow{3}{*}{13,345} & \multirow{3}{*}{, 000} & \multirow{3}{*}{$\begin{array}{c}a-b-c \\
b-c\end{array}$} \\
\hline & Amateur Male & 1,1912 & ,65237 & 07911 & & & \\
\hline & Professional Male & ,9118 & 66822 & ,11460 & & & \\
\hline \multirow{3}{*}{ Sleeping Pill Use } & Amateur Woman & ,0204 & 14286 & 02041 & \multirow{3}{*}{,448 } & \multirow{3}{*}{640} & \\
\hline & Amateur Male & , 0588 & ,29333 & 03557 & & & \\
\hline & Professional Male & ,0294 & , 17150 & ,02941 & & & \\
\hline \multirow{3}{*}{ Total PUKI Score } & Amateur Woman & 6,7143 & 3,26599 & 46657 & \multirow{3}{*}{12,267} & \multirow{3}{*}{, 000} & \multirow{3}{*}{$\begin{array}{c}a-b-c \\
b-c\end{array}$} \\
\hline & Amateur Male & 5,1618 & 2,54283 & 30836 & & & \\
\hline & Professional Male & 3,6176 & 2,66304 & ,45671 & & & \\
\hline
\end{tabular}

According to Table 3.3, the grouping of the participants according to the sports categories was examined. As a result of the analysis, no significant difference was found in the parameters of sleep duration, habitual sleep efficiency and sleep medication use ( $p>$ 0.05). However, when the BDI total score parameter was analyzed, it was found that there was a significant difference in favor of the amateur female group as a result of comparing the amateur women, amateur men and professional men groups $(p<0.05)$. When the BDI total score parameter was analyzed, it was found that there was a significant difference in favor of the professional male group as a result of the comparison between the amateur male group and the professional male group $(\mathrm{p}<0.05)$. When the subjective sleep quality, sleep latency, sleep disturbance and total PUKI score parameters were examined, a significant difference was found in favor of amateur women as a result of comparing the groups of amateur women, amateur men and professional men $(p<0.05)$. As a result of the examination made in these parameters, a significant difference was found in favor of the amateur male group as a result of comparing the amateur male and professional male groups $(\mathrm{p}<0.05)$.

\section{Discussion and Conclusion}

According to the data obtained in our study, when the participants were grouped according to sports category, when the BDI total score parameter was analyzed, it was seen that the average of the amateur female group was 17.49 \pm , the amateur male group was $11.12 \pm$ and the professional male group was 7.82 \pm . Considering the BDI scale scoring in this parameter, according to the scores obtained from the scale; Since it is known that 0-9 minimal, 10-16 mild, 17-29 moderate, and 60-63 severe depression symptoms are known, according to this score, the depression rate of the amateur female group was moderate in the covid-19 pandemic period, the amateur male group was mild and the professional male group was minimal. level appears.

Considering the reason for the high rate of depression in the amateur women group, it is thought that the high rate of depression may be due to the fact that women may have more responsibilities outside of their professional life than men. It is thought that the fact that the depression symptom of the professional male group is lower than 
the other groups may be related to the income level. When other studies in the literature are examined, it is thought that income level may be directly related to depression. $(7,8,9)$

When the PUKI total score parameter was examined in the grouping of the participants according to the sports category, it was seen that the average of the amateur female group was 6.71 \pm , the amateur male group was 5.16 \pm and the professional male group was 3.61. Considering the PUKI score in this parameter, it is known that the sleep quality of the people with a score of $1-5$ is good, and the sleep quality of the people with a score of 5-21 is considered; It is seen that the sleep quality of the athletes is good.

It is thought that the reason for this poor sleep quality in the group of amateur women is that they may have poor sleep quality because they deal with housework during the time they spend at home after working life. The studies carried out by Köybaş1 et al., Taşkıran et al. support our view, and they revealed that the sleep quality of women who are engaged in housework as a housewife or business woman is poor. $(10,11)$

When the PUKI total score parameter was examined in the grouping of the participants according to the sports category, it was seen that the average of the amateur female group was 6.71 \pm , the amateur male group was 5.16 \pm and the professional male group was 3.61. When the grouping of these participants by age was analyzed, when the total score of PSQI was analyzed, it was seen that the mean of the 18-23 age group was $5.65 \pm$, the mean of the 24-29 age group was $4.53 \pm$ and the mean of the 30-35 age group

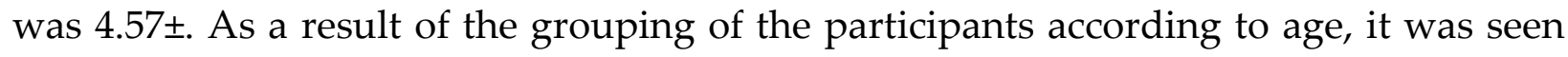
that the sleep quality of the 18-23 age group was poor, and the sleep quality of the 24-29 age group and 30-35 age group was good.

When the studies in the literature examining the sleep quality according to age were analyzed, it was observed that the sleep quality of the individuals decreased due to reasons such as snoring and disturbances that cause the sleep quality to deteriorate as they get older. When the data presented in this study and our data are compared, the worsening of sleep quality with increasing age does not overlap with our data. It is thought that this may be due to the fact that our sample group consists of athletes. The study by Stefan et al. was found to support our opinion. $(12,13)$

When other similar studies were examined, Dregan and Armstrong reported that the sleep quality rate of 16 -year-olds was $6 \%$, that of 23 -year-olds was $20 \%$, and that of 42 -year-olds was $36 \%$, and sleep quality worsened as age progressed. Contrary to these studies, there are also studies that do not show any significant difference between age and sleep quality. $(14,15)$

The aim of our study was to examine the mental health of amateur and professional football players during the Covid-19 pandemic period. For this purpose, a total of 151 football players including 49 amateur women, 68 amateur men and 34 professional men participated voluntarily. The Pittsburgh Sleep Quality Index was used to measure the sleep quality of the participants, and the Beck Depression Scale was used to determine their depression levels. The scales were presented to the participants in the digital environment due to the pandemic period. Statistical data of the responses received were made with the SPSS program. As a result of the analyzes made according to the 
athlete categories, when the PUKI total score parameter was examined, we found that the sleep quality values of amateur women and amateur men were high during the Covid19 pandemic period. High sleep quality values indicate poor sleep quality. Professional men were found to have good sleep quality. When the BDI total score was examined, we found that the depression symptoms of amateur women were moderate during the Covid-19 pandemic period, the depression symptoms of amateur men were mild, and professional men were minimal in the grouping by athlete category. According to the data revealed in the grouping made according to sports age, no significance was found in any of the parameters. When the BDI total score according to sports age was examined, we found that depression symptoms in all parameters were mild during the Covid-19 pandemic period. When we examined the PUKI total score values according to sports age, we found that the sleep quality of all parameters was bad. When the groupings according to age were examined, we found that the depression symptoms in the 18-23 age range in the Covid-19 period were moderate. We found that the athletes in the 24-29 age group and the 30-35 age group have minimal symptoms of depression during the Covid-19 pandemic period. When we examined the PUKI total score data in grouping by age, we found that the sleep quality of the athletes in the 18-23 age group was bad during the Covid-19 pandemic period. It has been observed that the sleep quality of 24-29 age group and 30-35 age group athletes is good during the Covid-19 pandemic period.

\section{Acknowledgement}

This article was created from a master's thesis.

\section{Conflict of Interest Statement}

There are no potential conflicts of interest on this article.

\section{About the Authors}

Hasan Akgün has a Master of Science degree in the sport science field.

Dr. Mürsel Biçer is Professor Doctor at Gaziantep University, Turkey.

Mehmet Vural is a research assistant at Gaziantep University, Turkey.

\section{References}

1. Lesser IA, Nienhuis CP. The impact of COVID-19 on physical activity behavior and wellbeing of Canadians. Int J Environ Res Public Health. 2020; 17: 11: 3899.

2. $\mathrm{Wu} \mathrm{Z}$, Mcgoogan JM. Characteristics of and important lessons from the coronavirus disease 2019 (COVID-19) outbreak in China: summary of a report of 72314 cases from the Chinese center for disease control and prevention. The Journal of the American Medical Association. 2020; 323: 13: 1239-1242. 
3. Burtscher J, Burtscher M, Millet GP. (Indoor) Isolation, stress and physical inactivity: vicious circles accelerated by Covid-19 Scandinavian Journal of Medicine \& Science in Sports. 2020; 30: 8: 1544-1545.

4. Nieman DC, Wentz LM. The compelling link between physical activity and the body's defense system. Journal of Sport and Health Science. 2019; 8: 3: 201-217.

5. Keskin V. Çocukların Spora Yönelmelerinde Anne Ve Babaların Beklentileri. Afyon Kocatepe Üniversitesi Sağlık Bilimleri Enstitüsü, Afyon, Yüksek Lisans Tezi, 2006;14.

6. Kazak H. İlköğretim Öğrencilerinin Spora Başlamasında Sosyal Faktörlerin Rolü. Sakarya Üniversitesi Sosyal Bilimler Enstitüsü, Sakarya, Yüksek Lisans Tezi,2010;16-42.

7. Yıldız H. G. Ortaöğretim Kurumları Spor Alanında Okuyan Öğrencilerin Spora Başlama Ve Bu Alanı Seçme Nedenleri İle Beklentileri. Gazi Üniversitesi Eğitim Bilimleri Enstitüsü, Ankara, Yüksek Lisans Tezi, 2006; 10-21.

8. Kaaya SF, Mbwambo JK, Kilonzo GP, Van Den Borne H, Leshabari MT, Fawzi MC, Et Al. Socio-Economic and Partner Relationship Factors Associated With Antenatal Depressi Vemor Bidity Among Pregnant Women İn Dar Es Salaam, Tanzania. Journal Of Healthresearch 2010;12(1):23-35.

9. Lee AM, Lam SK, Lau SM, Chong CS, Chui HW, Fong DY. Prevalence, Course, And Risk Factors for Antenatal Anxiety and Depression. Obstet Gynecol 2007;110:1102-12.

10. Redinger S, Norris SA, Pearson RM, Richter L, Rochat T. First Trimes Terantenatal Depression and Anxiety: Prevalence And Associated Factors In An Urban Population İn Soweto, South Africa. J Dev Orighealthdis 2017;Sep 7:1-11. Taşkıran N. Gebelik ve uyku kalitesi. J TurkSocObstetGynecol 2011; 8: 181- 7.

11. Şahin Köybaşı E, Yeşiltepe Oskay Ü. Gebelik sürecinin uyku kalitesine etkisi Gülhane Tip Dergisi 2017; 59:1-5.

12. Stefan, L., Sporis, G., Krističević, T., Knjaz, D., “Associations between sleep quality and its domains and insufficient physical activity in a large sample of Croatian young adults: a cross-sectional study", BMJ Open, 13, 8 (7), 2018.

13. Dregan, A., Armstrong, D., "Adolescence sleep disturbances as predictors of adulthood sleep disturbances--a cohort study", J Adolesc Health., 46 (5), 482-487, 2010

14. Dağ, B., Kutlu, F. Y., “The relationship between sleep quality and depressive symptoms in adolescents". Turk J. Med. Sci., 12, 47 (3), 721-727, 2017.

15. Bellini, M., Gemignani, A., Gambaccini, D., Toti, S., Menicucci, D., Stasi, C., Costa, F., Mumolo, M. G., Ricchiuti, A., Bedini, R., de, Bortoli, N., Marchi, S., "Evaluation of latent links between irritable bowel syndrome and sleep quality", World J Gastroenterol., 14, 17 (46), 2011 
Hasan Akgün, Mürsel Biçer, Mehmet Vural

INVESTIGATION OF MENTAL HEALTH OF AMATEUR AND PROFESSIONAL

FOOTBALL PLAYERS IN THE COVID-19 PANDEMIC PERIOD

Creative Commons licensing terms

Authors will retain the copyright of their published articles agreeing that a Creative Commons Attribution 4.0 International License (CC BY 4.0) terms will be applied to their work. Under the terms of this license, no permission is required from the author(s) or publisher for members of the community to copy, distribute, transmit or adapt the article content, providing a proper, prominent and unambiguous attribution to the authors in a manner that makes clear that the materials are being reused under permission of a Creative Commons License. Views, opinions and conclusions expressed in this research article are views, opinions and conclusions of the author(s). Open Access Publishing Group and European Journal of Physical Education and Sport Science shall not be responsible or answerable for any loss, damage or liability caused in relation to/arising out of conflict of interests, copyright violations and inappropriate or inaccurate use of any kind content related or integrated on the research work. All the published works are meeting the Open Access Publishing requirements and can be freely accessed, shared, modified, distributed and used in educational, commercial and non-commercial purposes under a Creative Commons attribution 4.0 International License (CC BY 4.0). 